\title{
RESEARCH OF GROWTH DYNAMICS OF SELECTED DECIDUOUS TREES FOR THE NEEDS OF LANDSCAPE ARCHITECTURE
}

\author{
Lenka Miksová1, Pavel Bulíŕr \\ ${ }^{1}$ Department of Planting Design, Faculty of Horticulture, Mendel University in Brno, Valtická 337, 69144 Lednice, \\ Czech Republic
}

Link to this article: https://doi.org/10.11118/actaun.2021.056

Received: 7. 11. 2019, Accepted: 26. 11. 2021

To cite this article: MIKSOVÁ LENKA, BULÍR PAVEL. 2021. Research of Growth Dynamics of Selected Deciduous Trees for the Needs of Landscape Architecture. Acta Universitatis Agriculturae et Silviculturae Mendelianae Brunensis, 69(6): 635-641.

\begin{abstract}
The main target of the research was to compare the growth dynamics of woody plants in relation to their age, specifically in individuals up to 10 years after planting. Five fast-growing species (Fraxinus excelsior, Populus alba, Populus nigra, Ulmus laevis, Ulmus minor) and four control species (Acer campestre, Carpinus betulus, Prunus avium, Tilia cordata) were selected. The model site is part of the regional biocentre in Brno. It is a warm area with an increased groundwater level. The planting took place in 2011. Evaluation was done at the turn of 2016/2017 and included measuring the following attributes: the overall height of the specimen, the annual increment of the terminal shoot and the annual increment of six lateral shoots. The highest average values were observed in Populus nigra which, in the context of close results of individual specimens, can be attributed the overall highest growth dynamics. The average terminal shoot increment exceeded $50 \mathrm{~cm}$ in all species except for Tilia cordata; in Populus alba and Populus nigra it exceeded $100 \mathrm{~cm}$. Generally, the values of Carpinus betulus, Prunus avium and Tilia cordata were mutually comparable and at the same time lower than the values of woody plants labelled as fast growing. The results for Acer campestre were close to the category of fast-growing species.
\end{abstract}

Keywords: growth dynamics, fast-growing trees, landscape architecture

\section{INTRODUCTION}

From the landscape architecture point of view, growth dynamics is an important compositional feature. Combining woody plants with various growth dynamics enables to work with space during the development of garden and landscape design objects. The speed of growth has an impact not only on the overall functionality of the composition, but also on the properties of each specimen, its proportions, form, texture and variability during the development. Fast-growing woody plants play an irreplaceable role in landscape architecture in connection with an early development of functionality.
Research dealing with the issues of growth dynamics from the landscape architecture point of view is virtually non-existent. Fast-growing woody plants are a frequently discussed topic especially at the level of searching for renewable energy sources (Szostak et al., 2013). There are numerous studies which compare biomass yield of selected species and clones under different conditions (Aravanopoulos, 2010; Benetka, Novotná and Štochlová, 2014; Štochlová et al., 2019). Non-production functions of fast-growing tree plantations, such as their impact on biodiversity and landscape water regime (Havlícková and Rudisová, 2011) are also investigated. 
The term fast-growing woody plant often remains to be defined at the level of a faster production of wood biomass in young plants (Szostak etal., 2013). The speed of growth is usually evaluated in particular in terms of volume of wood mass annual production per area unit; in fast-growing taxa this amounts to at least $10 \mathrm{~m}^{3}$ per hectare (FAO, 1965; IUFRO, 2005; Petř́ḱková and Weger, 2015). From the landscape architecture point of view, the primary criterion for evaluating growth dynamics is mainly the size of height increment. The specific length of annual height increment for fast-growing species was defined by Weger (2011) at the value of at least $0.5 \mathrm{~m}$ in 1year old plants, and at least $1 \mathrm{~m}$ in older plants. Kolesnikov (1974) worked with the value of more than $0.5-0.6 \mathrm{~m}$ for fast-growing species; he labelled plants with an annual height increment over $1 \mathrm{~m}$ as very fast growing.

Accessible publications on woody plants for orchard and landscape purposes do not in principle specify the values of annual increment, nor do they define based on which values the species were or were not classified as fast growing (e.g. Belke and Gaida, 1991; Hieke, 1994; Hurych, 2003; Bruns, 2013). Some publications contain only the size of adult plants (e.g. Horáček, 2007; Hieke, 2008; Málek, Horáček and Kiesenbauer, 2012). Bruns (2013) states for many species the values of annual increments in height and width, but without any connection to the age of the plant. In the 1960s, field studies in parks of the former Czechoslovakia were conducted, in which among others the values of crown height and width were ascertained in selected deciduous trees for five age categories (Kavka, 1969). However, the published data do not contain all taxa commonly used today in landscape design. Moreover, they focus only on the functional type of park greenery. More detailed data are provided by Vreštiak (1991) who examined the development of biomass in 40 most commonly used deciduous trees in selected Slovak cities in categories of 5-year intervals up to a maximum of 80 years of age (in proportion to the lifespan of the individual taxa).

From the landscape architecture point of view, the absence of information on dimensions of woody plants in connection with their age may lead to mistakes and insufficient utilization of the plant potential. Woody plants with considerable growth dynamics can be used for filling spaces, for instance in newly created elements of residential and landscape greenery. On the contrary, when using fast-growing species in places with significant space limitations, the plant may soon grow to undesirable proportions which must be corrected by pruning. It may result in worsening the esthetical and functional state of the plant and at the same time in increasing the expert and financial demands for maintenance. Systematic research of growth dynamics of woody plants might contribute to their adequate use.

\section{MATERIALS AND METHODS}

The experimental plot is part of the regional biocentre Ráječek in the municipal district BrnoČernovice. The locality is situated in the first altitudinal zone, approximately $195 \mathrm{~m}$ above sea level. It belongs to the T4 warm climate region (Agentura, 2012). According to the meteorological station Brno-Turany, which is closest to the model locality, the average air temperature in 2016 was $10.6^{\circ} \mathrm{C}$, the annual precipitation amounted to $524 \mathrm{~mm}$ (Český, 2019). In terms of biogeographical zoning, the area is part of the Pannonian biogeographical province. Potential vegetation consists of oak-hornbeam forest (Primulo-veris Carpinetum) and elm-oak forest (Querco-Ulmetum) (Agentura, 2012). Geological subsoil is made of fluvial loamy sediments (Česká, 2014). There is waterlogged soil with regularly varying groundwater level on the site (ZO ČSOP, 2019).

The evaluated specimens are situated inside an area 1.25 hectare within five separate groups that are planted of assortment of five fast-growing species (Fraxinus excelsior, Populus alba, Populus nigra, Ulmus laevis, Ulmus minor) and four species with a standard speed of growth (Acer campestre, Carpinus betulus, Prunus avium, Tilia cordata). The furthermost groups are planted $170 \mathrm{~m}$ apart. The local site conditions are entirely comparable for all groups. Each group consists of approx. 175 trees planted with the spacing of $1.5 \mathrm{~m}$. The planting took place in 2011. The planting material were bare-rooted young plants, transplanted twice. The plants were watered when planted (401/piece) and mulched with wood chips (layer thickness $5 \mathrm{~cm}$ ). When planting and during the follow-up care no fertilizers were applied and no pruning was conducted. In the first year, weeding and checking the mulch was done twice. The plants were watered 5 times with 401/piece (Kaisler, 2016).

Five specimens of each observed species were evaluated in each group, i.e. 25 specimens for each species, in total 225 pieces. Within each particular group measurements were done on developmentally medial specimens, which showed increase in all evaluated parameters and had at least seven undamaged shoots. The measuring included the following parameters: tree height, annual terminal shoot increment, annual increment of six lateral shoots. The tree height was determined as the distance from the base of the trunk to the treetop, measured by a levelling rod. Annual increments were determined as the length of the current-year shoots after the end of growth (evaluation was done after leaf fall in the time of vegetation dormancy), they were measured with a measuring tape if accessible, or using a levelling rod. All values had the accuracy of $\mathrm{cm}$. Should the terminal shoot be damaged, the highest shoot was measured. If more equal shoots were identified, without one clearly dominant shoot, all of them 
were measured and the value of the longest one was counted. Lateral shoots were measured using a unified scheme: two shoots nearest the terminal shoot; further the height of $1.5 \mathrm{~m}$ from the trunk base was marked and the four shoots upwards nearest from this border were measured. If there were not enough undamaged shoots above this border, shoots downwards were measured too. In case of several shoots growing from one place, all of them were measured and the values of the longest ones were counted. Always the living, undamaged shoots showing growth were measured.

The established data were evaluated using Microsoft Excel and Statistica. The analysis of variance ANOVA with interactions was used. For each parameter, the arithmetic mean, standard deviation, maximum and minimum values were determined for individual species.

\section{RESULTS AND DISCUSSION}

Growth dynamics of woody plants can be determined based on various parameters. From the landscape architecture point of view, the annual height increment is fundamental. The increments of terminal shoots can be seen in Tab. I. The highest average annual increment was observed in Populus nigra $(135.4 \mathrm{~cm})$, with a standard deviation of $22.96 \mathrm{~cm}$. The values ranged between 100 and $189 \mathrm{~cm}$. The average value exceeded $100 \mathrm{~cm}$ also in Populus alba; however, the standard deviation was $33.79 \mathrm{~cm}$. There were considerable differences between the specimens. The lowest value was $48 \mathrm{~cm}$, the highest $166 \mathrm{~cm}$.

All control taxa (Acer campestre, Carpinus betulus, Prunus avium, Tilia cordata) achieved similar average increments of the terminal shoot (between 50 and $67 \mathrm{~cm}$ ). A comparable value was also observed in Ulmus laevis, but there was a considerable standard deviation at the same time. The lowest measured value was $28 \mathrm{~cm}$, the highest increment was $160 \mathrm{~cm}$. The result may be a consequence of an irregular growth of the species, where there was often not one terminal shoot but several equal shoots. Thus, the potential growth energy of the tree could be divided among several shoots, out of which none created a dominant increment.

According to Kolesnikov (1974), based on the length of increments, all taxa could be classified as fast growing (annual height increment of at least $50 \mathrm{~cm}$ ). The smallest increment was observed in Tilia cordata $(49.80 \mathrm{~cm})$, all other species exceeded $50 \mathrm{~cm}$. When interpreting the results, it is however necessary to consider the fundamental factors of the experiment, mainly the age of the plants, conditions of the site and the character of the experiment that took place at model site in non-urban area during limited period of one year. The specimens are young, well rooted. The environmental requirements of the species in the given situation correspond to the natural conditions of the site. In comparison with the long-term average of the years 1981-2010, the year 2016 with its average annual temperature and the annual precipitation amount was slightly higher than average (Český, 2019). Kolesnikov (1974) does not specify to which age of the trees his published data refer. Had the experiment been conducted in adult specimens, the increments would probably have been smaller. Similarly, smaller overall increases probably would be observed for woody plants growing in a less favourable site conditions in urban area. In case of long-term observation, there could also have been deviations between individual years. The overall increment may also be influenced by the planting spacing, which was only $1.5 \mathrm{~m}$. It is possible that the trees then grow more upwards, than they would have grown, had they been planted with larger spacing.

The comparison of data in Tab. I clearly shows that similar values of annual increments of terminal shoot were measured only in Prunus avium. Bruns (2013) states $50 \mathrm{~cm}$, the average value of measured

I: Annual shoot increments - comparison of the experiment data (2016/2017) with data published in Bruns (2013)

\begin{tabular}{|c|c|c|c|c|c|}
\hline \multirow{2}{*}{ Species } & \multicolumn{3}{|c|}{$\begin{array}{l}\text { Annual increment } \\
\text { of terminal shoot }(\mathrm{cm})\end{array}$} & \multicolumn{2}{|c|}{$\begin{array}{c}\text { Annual increment } \\
\text { of selected lateral shoots }(\mathrm{cm})\end{array}$} \\
\hline & Average & Stand. deviation & Bruns, 2013 & Average & Stand. deviation \\
\hline Acer campestre & 65.00 & 28.64 & $40-45$ & 47.44 & 7.59 \\
\hline Carpinus betulus & 66.56 & 17.33 & 35 & 39.85 & 9.26 \\
\hline Fraxinus excelsior & 73.40 & 26.65 & $30-45$ & 55.36 & 6.00 \\
\hline Populus alba & 102.84 & 33.79 & not stated & 73.22 & 19.86 \\
\hline Populus nigra & 135.40 & 22.96 & 70 & 77.78 & 9.04 \\
\hline Prunus avium & 53.56 & 14.02 & 50 & 39.13 & 9.35 \\
\hline Tilia cordata & 49.80 & 15.43 & 30 & 36.35 & 9.01 \\
\hline Ulmus laevis & 64.92 & 31.43 & $40-50$ & 43.79 & 14.59 \\
\hline Ulmus minor & 86.68 & 31.22 & 40 & 53.33 & 7.95 \\
\hline
\end{tabular}


II: Tree height - comparison of own data (2016/2017) with the data of other authors (for the age category up to 10 years)

\begin{tabular}{lcccc}
\hline \multirow{2}{*}{ Species } & \multicolumn{4}{c}{ Height $(\mathrm{m})$} \\
\cline { 2 - 5 } & Average & Stand. deviation & Kavka, 1995 & Vreštiak, 1991 \\
\hline Acer campestre & 3.27 & 0.5803 & $0.8-1.5$ & 2.9 \\
Carpinus betulus & 2.59 & 0.2820 & $2-5$ & 4.2 \\
Fraxinus excelsior & 2.81 & 0.3873 & $3-4$ & 5.3 \\
Populus alba & 3.85 & 0.8061 & $6-8$ & 9.4 \\
Populus nigra & 3.92 & 0.3702 & $3-6$ & 5.6 \\
Prunus avium & 2.51 & 0.3142 & $3-4$ & not stated \\
Tilia cordata & 2.01 & 0.3247 & $1.5-3$ & 4.3 \\
Ulmus laevis & 3.40 & 0.5086 & $1.5-4$ & not stated \\
Ulmus minor & 3.61 & 0.6362 & $2-5$ & not stated \\
\hline
\end{tabular}

specimens was $53.56 \mathrm{~cm}$. All other species deviate considerably, with the measured values being always higher, e.g. in Ulmus minor more than twice. Bruns (2013) does not state to how old specimens the annual height increment refers. It cannot be identified whether the data come from the period of growth culmination, or whether this is for instance a long-term average. Moreover, the evaluation was conducted in tree nursery sites, whereas the measured values refer to plants on their permanent site, where the measurements were done only during one year. Hence it is necessary to understand the results as preliminary.

Apart from the terminal shoot increment, Tab. I also shows the average value of six measured lateral shoots. None of the species came close to the value of $100 \mathrm{~cm}$. The highest average increment was observed again in Populus nigra $(77.78 \mathrm{~cm})$ and Populus alba $(73.22 \mathrm{~cm})$. The increments exceeding $50 \mathrm{~cm}$ were further identified in Fraxinus excelsior $(55.36 \mathrm{~cm})$ and Ulmus minor $(53.33 \mathrm{~cm})$. Although a certain distortion given by the selection of measured shoots according to the unified scheme can be expected, the classification of the mentioned species as woody plants with high growth dynamics was confirmed.

Average lateral shoots increments are smaller than terminal shoot increments, which corresponds to the type of branching of the evaluated species. At the same time, the standard deviations and the differences of minimum and maximum measured values for the individual species were larger in the terminal shoot than in the lateral shoots. The values of six measured lateral shoots thus contain less extreme values within the individual taxa than the terminal shoot increments.

Tab. II shows results summarizing the identified average heights of the evaluated species. The highest average height was observed in Populus nigra (3.92 m), whereas the standard deviation was among the smallest $(0.37 \mathrm{~m})$. The lowest measured figure was $3.12 \mathrm{~m}$, the highest one was $4.6 \mathrm{~m}$.
In Populus alba, the average height was similar to the previous species $(3.85 \mathrm{~m})$ but the standard deviation was clearly the highest $(0.81 \mathrm{~m})$. The smallest evaluated specimen measured $2.5 \mathrm{~m}$, the highest one had $6.25 \mathrm{~m}$. On the whole, the average height of fast-growing species exceeded $2.8 \mathrm{~m}$. In Carpinus betulus, Prunus avium and Tilia cordata the height was between $2.0 \mathrm{~m}$ and $2.6 \mathrm{~m}$. The results confirmed the assumption that fast-growing woody plants achieve larger sizes earlier than species with standard speed of growth. The exception is Acer campestre which with its average height of $3.27 \mathrm{~m}$ is comparable with fast-growing trees.

It follows from the analysis of situation that the site conditions were comparable and favourable for all observed species. At the same time these are domestic species which, in this kind of sites, should have increments even without any additional care (which is common in a number of sites in residential greenery for instance). Despite that, some specimens of Populus alba showed small increments, or practically stagnated in their growth. A possible cause of the unbalanced results can also be a technological error during the planting which caused a slow-down of growth. Another cause can also be a certain natural variability within the species and the propagation material.

It further follows from Tab. II that the values stated by Kavka (1995) are closest to the results of the field research. Specifically, in the species Carpinus betulus, Populus nigra, Tilia cordata, Ulmus laevis and Ulmus minor, the observed average height corresponds to the stated range. In Fraxinus excelsior and Prunus avium, the measured figures are lower by 0.2 and $0.5 \mathrm{~m}$. The average height of Populus alba $(3.85 \mathrm{~m})$ does not come even close to the stated range of 6-8m. However, the result does not directly indicate low growth dynamics. The lower growth of the mentioned species can also be caused by a practically absent care after planting and less mature nursery stock, whereas Kavka (1995) evaluated trees in parks, where 
III: Minimum and maximum measured values of parameters for individual taxa

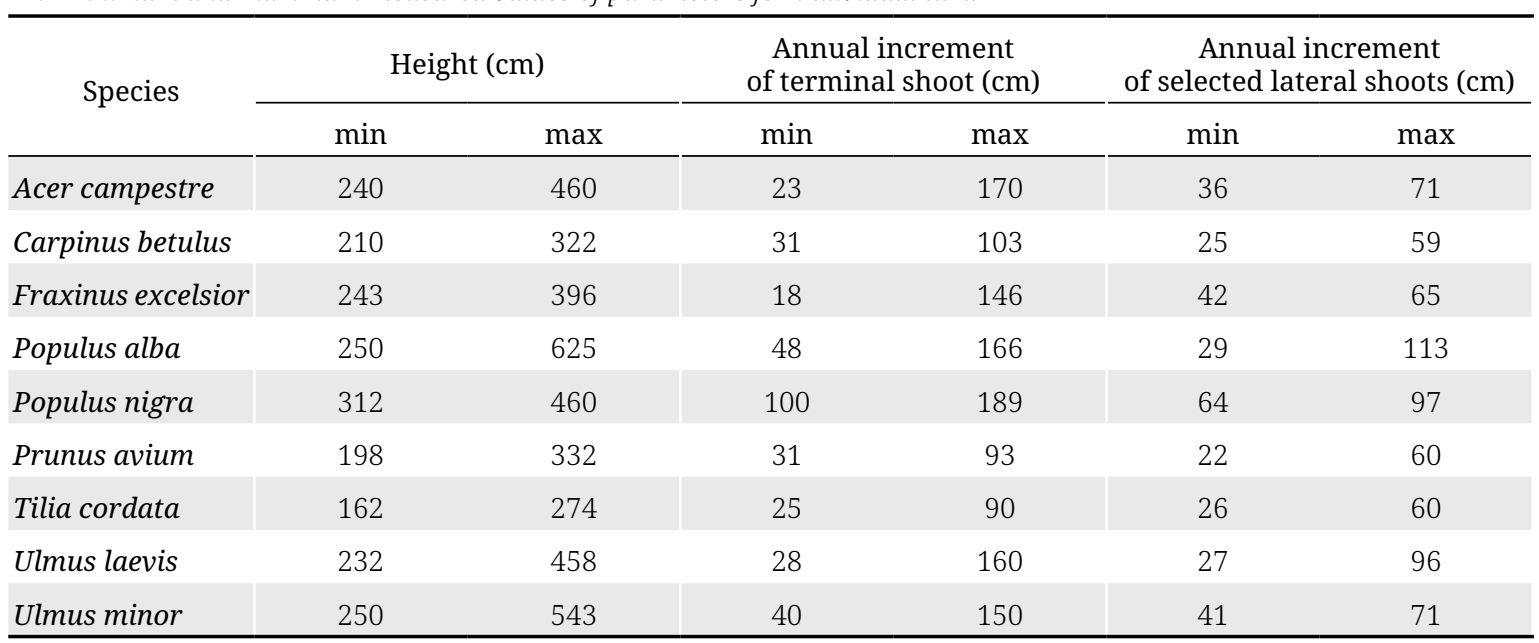

the usage of higher quality nursery stock as well as a higher level of the follow-up care can be expected. A distinctive difference in values was observed also in Acer campestre, whose height at the given age should not exceed $1.5 \mathrm{~m}$ (Kavka, 1995); the identified average value on the site, however, was more than twice as much $(3.27 \mathrm{~m})$, whilst the smallest evaluated specimen reached $2.4 \mathrm{~m}$. Considering the comparison of similarly old specimens and despite the possible influence of climatic conditions, the result preliminarily indicates a higher growth dynamics. The hypothesis of higher growth dynamics is also supported by the comparison with Vreštiak (1991), who evaluated solitary healthy specimens in urban greenery outside extreme sites. He partly calculated the values by means of compensation polynomials. His records state the height of $2.9 \mathrm{~m}$ for Acer campestre. At the same time, for Carpinus betulus, Fraxinus excelsior, Populus nigra, Populus alba and Tilia cordata he states higher values; the comparison for Prunus avium, Ulmus laevis and Ulmus minor is missing. Considering the character of the realised experiment which was limited to a one year period due to the realised treatment (cutting), it needs to be emphasized that the presented data comparisons are only preliminary despite the similarly old plants, and further research and verification over time are necessary.

The general overview of minimum and maximum values for the monitored parameters is stated in Tab. III. The lowest number of extreme results was identified in Populus nigra. By contrast, big differences in all parameters were observed in Populus alba. The highest evaluated tree was 2.5 times higher than the smallest specimen. The longest terminal shoot achieved approximately 3.5 times the value of the shortest one. High growth dynamics of Acer campestre was also confirmed. In the terminal shoot, there was a considerable difference between the smallest and highest identified figure; however, in the overall height and annual lateral shoots increment, the minimum measured values were higher than in other control plants.

\section{CONCLUSION}

It follows from the measured figures that Populus nigra showed the highest growth dynamics, Tilia cordata the lowest. On the whole, the species classified as fast growing (Fraxinus excelsior, Populus alba, Populus nigra, Ulmus laevis, Ulmus minor) reached higher results than trees with a standard speed of growth (Carpinus betulus, Prunus avium, Tilia cordata). An exception was Acer campestre which was with its results closer to Fraxinus excelsior and Ulmus laevis. For instance, the comparison of the average height of the slowest growing representative of fast-growing woody plants (Fraxinus excelsior $2.81 \mathrm{~m}$ ) with the fastest growing species from the second category (Prunus avium $2.51 \mathrm{~m}$ ) showed a difference of $30 \mathrm{~cm}$ in favour of the fast-growing category. The average height of Acer campestre amounted to $3.27 \mathrm{~m}$. When comparing the maximum length of annual terminal shoot increment, the fast-growing woody plants exceeded $146 \mathrm{~cm}$ (Fraxinus excelsior), whereas in the control plants a maximum of $103 \mathrm{~cm}$ was reached (Carpinus betulus). The maximum length in Acer campestre was $170 \mathrm{~cm}$. Despite this, only one of the used resources (Belke and Gaida, 1991) ranks this species among fast-growing woody plants.

The results of the experiment have showed higher growth dynamics in the genus Populus in comparison with other evaluated fast-growing species. Only in the species Populus alba and Populus nigra, the average value of the annual increment of terminal shoot exceeded $1 \mathrm{~m}$. 
When interpreting the results, it is necessary to consider the fact that they reflect the growth dynamics of young individuals of selected species during one year on one model locality in non-urban area with favourable site conditions. The growth characteristics of the same woody species planted in less favourable conditions and urban sites may be different. For this reason, further long-term observations on various model sites are desirable. Nevertheless, the established preliminary data are valuable for the usage of woody plants in Landscape architecture. For instance, based on the results the frequency of treatment of the trees can be appropriately modified in similar types of sites (landscape or residential), in particular specific pruning interventions, improvement cutting can be better planned, or specific changes in the spatial arrangement of vegetation elements can be implemented. After further verification and supplementation of the presented results the growing methods can be similarly modified even in less favourable growing site within the garden and landscape designs. Likewise, further time-verified results can be used for planning of complex renewal or regeneration interventions in residential and landscape greenery and for its planting.

\section{REFERENCES}

AGENTURA OCHRANY PǨÍRODY A KRAJINY ČESKÉ REPUBLIKY. 2012. MapoMat. [Online]. Available at: http://mapy.nature.cz/ [Accessed: 2018, February 6].

ARAVANOPOULOS, F. 2010. Breeding of fast growing forest tree species for biomass production in Greece. Biomass, 34(11): 1531-1537.

BELKE, H. J. and GAIDA, W. 1991. Wood Species in Town and Landscape: A guide to using trees and shrubs [in German: Gehölze in Stadt und Landschaft: Ein Leitfaden zur Verwendung von Bäumen und Sträuchern]. Band II. Hamburg: Ernst Wohlt Baumschulen.

BENETKA, V., NOVOTNÁ, K. and ŠTOCHLOVÁ, P. 2014. Biomass production of Populus nigra L. clones grown in short rotation coppice systems in three different environments over four rotations. IForest-Biogeosciences, 7(4): 233-239.

BRUNS, J. 2013. Bruns Pflanzen - Catalogue of trees and shrubs 2013/2014. Bad Zwischenahn: Bruns Pflanzen-Export GmbH \& Co.KG.

ČESKÁ GEOLOGICKÁ SLUŽBA. 2014. Geological map 1:25 000 [in Czech: Geologická mapa 1:25 000]. Geovědnímapy. [Online]. Available at: http://mapy.geology.cz/geocr_25/ [Accessed: 2018, February 6].

ČESKÝ HYDROMETEOROLOGICKÝ ÚSTAV. 2019. Daily data: Brno Tuřany [in Czech: Denní data: Brno Tuřany]. ČHMÚ. [Online]. Available at: http://portal.chmi.cz/historicka-data/pocasi/denni-data\# [Accessed: 2019, May 30].

FAO. 1965. Fast-growing tree species for industrial plantations in developing countries. condensed version of a paper contributed by FAO to a meeting of the United Nations Advisory Committee on the Application of Science and Technology to Development. Available at: http://www.fao.org/ docrep/30289e/30289e02.htm. [Accessed: 2018, August 3].

HAVLÍCKOVÁ, K. and RUDISOVÁ, I. 2011. A Short rotation coppice of fast-growing trees, their landscape aspects and biodiversity. Ekológia, 30(1): 12-21.

HIEKE, K. 1994. Lexicon of ornamental woody species [in Czech: Lexikon okrasných dřevin]. Praha: Helma.

HIEKE, K. 2008. Encyclopedia of coniferous trees and shrubs [in Czech: Encyklopedie jehličnatých stromů a keřul. Brno: Computer Press.

HORÁČEK, P. 2007. Encyclopedia of deciduous trees and shrubs [in Czech: Encyklopedie listnatých stromů a keřu ]. $2^{\text {nd }}$ Expanded Edition. Brno: Computer Press.

HURYCH, V. 2003. Ornamental woody species for gardens and parks [in Czech: Okrasné dřeviny pro zahrady a parky]. 2 ${ }^{\text {nd }}$ Expanded Edition. Praha: Květ.

IUFRO. 2005-2015. 4.04.02 - Planning and economics of fast-growing plantation forests. IUFRO. [Online]. Available at: https://www.iufro.org/science/divisions/division-4/40000/40400/40402/ [Accessed: 2018, August 3].

KAISLER, R. 2016. Project documents, part of regional biocentre Ráječek: tatement of cost [in Czech: Projektová dokumentace, část regionálního biocentra Ráječek: výkaz výměr]. KAISLER, s. r. o.

KAVKA, B. and KOLAŘÍK, J. 1995. Landscaping Dendrology I: Deciduous trees [in Czech: Sadovnická dendrologie I. Listnaté stromy]. $1^{\text {st }}$ Arranged Edition. Brno: EDEN.

KAVKA, B. 1969. Evaluation of the main species of deciduous trees in aspect of their usage in Garden and Landscape architecture [in Czech: Zhodnocení hlavních druhů listnáču z hlediska jejich využití $v$ zahradní a krajinářské architektuře]. Průhonice: Výzkumný ústav okrasného zahradnictví.

KOLESNIKOV, A. I. 1974. Ornamental Dendrology [in Russian: Dekorativnaja dendrologija]. Moskva: Lesnaja promyšlenost. 
MÁLEK, Z., HORÁČEK, P. and KIESENBAUER, Z. 2012. Trees for Towns and Landscape [in Czech: Stromy pro sídla a krajinu]. Olomouc: Petr Baštan in cooperation with the company Arboeko.

PETŘÍKOVÁ, V. and WEGER, J. 2015. Growing plants for energy and technical usage: biomass, biogas, feed [in Czech: Pěstování rostlin pro energetické a technické využití: biomasa, bioplyn, krmiva]. Praha: Profi Press.

ZO ČSOP VERONICA. 2019. Ráječek and nature reserve Černovický hájek [in Czech: Ráječek a př́rodní rezervace Černovický hájek]. Veronica. [Online]. Available at: https://www.veronica.cz/rajecek [Accessed: 2019, June 30].

SZOSTAK, A., BIDZIŃSKA, G., RATAJCZAK, E. et al. 2013. Wood biomass from plantations of fast-growing trees as an alternative source of wood raw material in Poland. Drewno, 56(190): 85-113.

ŠTOCHLOVÁ, P., NOVOTNÁ, K., COSTA, M. et al. 2019. Biomass production of poplar short rotation coppice over five and six rotations and its aptitude as a fuel. Biomass, 122: 183-192.

VREŠTIAK, P. 1991. Development of leaf biomass in the structure of urban greenery [in Slovak: Vývoj listovej biomasy $v$ štruktúre sídelnej zelene]. Bratislava: Veda.

WEGER, J. 2011. Fast-growing woody species: Basic description [in Czech: Rychle rostoucí dřeviny: Základní popis]. Výzkumný ústav Silva Taroucy pro krajinu a okrasné zahradnictví, v. v. i. [Online]. Available at: http://www.vukoz.cz/index.php/rychle-rostouci-dreviny/zakladni-popis [Accessed: 2018, August 3]. 
